\title{
The Demographics of Covid-19 in the European Union
}

\author{
By Gregory T. Papanikos *
}

\begin{abstract}
This paper provides provisional descriptive evidence to answer two questions which relate to deaths due to COVID-19 in EU countries. First, to what extent variations in population sizes matter in EU countries? Can variations in deaths per capita (or people infected per capita) be explained by variations in population sizes? Second, does the economy matter? Can variations in total and per capita GDP explain variations in deaths per capita? Related is the issue of social spending. Can social spending explain variations in COVID-19 impacts? In answering these questions, data from EU member states are used. Simple stepwise descriptive statistical analyses show that population sizes and economies do matter in explaining the observed variations in COVID-19 impacts. It is found that only deaths per capita give meaningful and statistically significant results. This relation is non-linear. On average a one percent rise in population size increases deaths per capita by $0.49 \%$.
\end{abstract}

Keywords: COVID-19, European Union, Population, GDP, Per Capita GDP, Social Policy

\section{Introduction}

Never before in history world population was so large, so old, so much travelling across the globe and so interconnected via technology. In the last millennium, the world has witnessed tremendous population growths despite the positive and preventive checks that so eloquently have been examined by Malthus in his famous book on An Essay on the Principle of Population first published in 1798. There is no doubt that technology has been the primary factor explaining this unprecedented growth in global population especially vaccines and human capital which has increased personal hygiene practices (Lee 2003).

Over the last centuries, these population upsurges have occurred in the midst of (a) catastrophic wars, (b) famines, and (c) natural disasters. The latter include lethal contagious diseases. But as Malthus (1798: 110) remarked these did not affect the population because of "... the greatest proportion of births to burials, was in the five years after the great pestilence". In other words, population losses were recovered in few years.

The same was highlighted by Thucydides in his book The Peloponnesian War $^{1}$. Ten years after the plague, which struck Athens in the summer of 430 BCE, was forgotten, population rose sufficiently to support with fresh fighters a military expedition to Sicily and with a sufficient rise in public revenue.

\footnotetext{
*President, Athens Institute for Education and Research (ATINER), Greece.

${ }^{1}$ I have examined elsewhere the Ancient Plague of Athens in comparison with the current pandemic; see Papanikos (2020a). Similarly using a simulation model, Court and McIsaac (2020) concluded that in case of collapses, their model responded with higher than usual birth rates resulted in larger and younger population. It seems that this is the case with the current pandemic given the disproportionate effect on older populations.
} 
Presumably the ancient pestilence did not affect as hard the young generation. Only 15 years had elapsed since the plague which was more lethal during its second and last wave of 427 BCE. Those born after the plague would have been less than 12 years old at the time of the war in Sicily and could not serve as soldiers. This prompts the conclusion that those who were children at the time of the Plague of 430-427 BCE were not infected as much as older people otherwise would not have survived to join the ranks of the Athenian army. I mention this because relates to unequal impacts that pandemics may have on population in terms of age and gender.

This paper looks at demographic impact of COVID-19 in European Union (EU). My interest is policy oriented. The EU members may take a collective action to fight the pandemic or any future contagious disease and implement a common social policy. These policies are simply mentioned in the fourth section of this paper. In the following two sections, I compare the number of people infected and deaths of the pandemic in the EU member states in terms of their population sizes and age structure (section two) and its association with the size of EU economies and social policy spending (section three). The final section concludes.

My analysis here is basic. I use descriptive statistical tools to examine the issues and questions concerning this paper. I do not provide any literature review of the social and economic impact because this has been done in a paper I have already mentioned and another paper which looked at economic and tourism impacts of COVID-19 on Greek economy ${ }^{2}$.

\section{To What Extent Population Sizes Matter?}

Data on total people infected (cases) and the number of people died from COVID-19 were retrieved from the World Health Organization (WHO); it includes deaths and cases reported as of 31 May 2020 (https://covid19.who.int/). Population and economic statistics are retrieved from Eurostat (https://ec.europa. eu/eurostat/web/national-accounts/overview. The most recent available data on population, GDP and social policy are used as of 31 May 2020.

Table 1 reports basic statistics of all 27 countries which are members of EU: total population, total number of people infected, total number of people infected per million of population, total number of people died by the disease, total number of people died per million of population, and the death per cases ratio.

A few comments on data limitations are in order here. The number of cases reported has been very controversial not only in EU countries but in other countries as well. The total number of people infected is underreported because does not include all those who were infected and for various reasons were never tested, e.g., lack of medical resources, no symptoms etc.

\footnotetext{
${ }^{2}$ Based on scenario analysis, economic and tourism impacts were found to be unprecedented for non-war period; see Papanikos (2020b).
} 
The death statistics are more reliable but even these possibly are underestimated. People who died outside the health system (hospitals and clinics) may not be counted as victims of the pandemic. In any case, the issue here is whether these data biases differ between the EU countries. For the cases this may be true. However, the death variable may measure intra-EU variations more accurately. I will concentrate more on death variations, which, for all practical purposes, are more important. Those who were infected and survived may be a gain to society if they have become immune to the disease.

Table 1. Total Population, Case and Deaths in the European Union Member States

\begin{tabular}{|c|c|c|c|c|c|c|}
\hline Country & $\begin{array}{c}\text { Population } \\
\text { (2020 estimate) }\end{array}$ & Deaths & Cases & $\begin{array}{c}\text { Deaths per Million } \\
\text { People }\end{array}$ & $\begin{array}{c}\text { Cases per } \\
\text { Million People }\end{array}$ & $\begin{array}{c}\text { Deaths } \\
\text { per } \\
\text { Cases }\end{array}$ \\
\hline Belgium & 11542 & 9453 & 58186 & 819 & 6155 & 0.1625 \\
\hline Bulgaria & 6939 & 140 & 2513 & 20 & 17950 & 0.0557 \\
\hline Czechia & 10710 & 319 & 9230 & 30 & 28934 & 0.0346 \\
\hline Denmark & 5843 & 571 & 11633 & 98 & 20373 & 0.0491 \\
\hline Germany & 83270 & 8500 & 181482 & 102 & 21351 & 0.0468 \\
\hline Estonia & 1331 & 67 & 1865 & 50 & 27836 & 0.0359 \\
\hline Ireland & 4962 & 1651 & 24929 & 333 & 15099 & 0.0662 \\
\hline Greece & 10652 & 175 & 2915 & 16 & 16657 & 0.0600 \\
\hline Spain & 47217 & 29043 & 239600 & 615 & 8250 & 0.1212 \\
\hline France & 66945 & 28717 & 148436 & 429 & 5169 & 0.1935 \\
\hline Croatia & 4054 & 103 & 2246 & 25 & 21806 & 0.0459 \\
\hline Italy & 60314 & 33340 & 232664 & 553 & 6979 & 0.1433 \\
\hline Cyprus & 890 & 17 & 943 & 19 & 55471 & 0.0180 \\
\hline Latvia & 1908 & 24 & 1065 & 13 & 44375 & 0.0225 \\
\hline Lithuania & 2790 & 70 & 1670 & 25 & 23857 & 0.0419 \\
\hline Luxembourg & 632 & 110 & 4016 & 174 & 36509 & 0.0274 \\
\hline Hungary & 9752 & 524 & 3867 & 54 & 7380 & 0.1355 \\
\hline Malta & 516 & 7 & 616 & 14 & 88000 & 0.0114 \\
\hline Netherlands & 17482 & 5951 & 46257 & 340 & 7773 & 0.1287 \\
\hline Austria & 8921 & 668 & 16638 & 75 & 24907 & 0.0401 \\
\hline Poland & 37922 & 1061 & 23571 & 28 & 22216 & 0.0450 \\
\hline Portugal & 10274 & 1396 & 32203 & 136 & 23068 & 0.0433 \\
\hline Romania & 19294 & 1253 & 19133 & 65 & 15270 & 0.0655 \\
\hline Slovenia & 2097 & 108 & 1473 & 52 & 13639 & 0.0733 \\
\hline Slovakia & 5461 & 28 & 1521 & 5 & 54321 & 0.0184 \\
\hline Finland & 5530 & 316 & 6826 & 57 & 21601 & 0.0463 \\
\hline Sweden & 10373 & 4395 & 37113 & 424 & 8444 & 0.1625 \\
\hline
\end{tabular}

Source: COVID-19 from WHO (https://covid19.who.int/) and all others from the European Union (https://ec.europa.eu/eurostat/web/national-accounts/overview).

By looking at the raw data of Table 1, there appears to be huge differences between countries with similar populations. For example, Austria, Belgium, Czechia, Greece, Hungary, Portugal and Sweden, with a population of about 10 million people, have reported different impacts on total number of people died from the disease: 668, 9453, 319, 175, 524, 1396 and 4395 respectively. From the surprisingly low statistic of Greece of 175 deaths as of 31 May 2020 to the huge and unexpected number of 9,453 reported by Belgium.

On the other hand, Germany and France -the two countries with the largest populations in EU-, have reported striking different numbers of deaths. Germany 
with a population of 83 million people reported 8.5 thousand deaths while France with 67 million population had three times higher this number $(28,717)$. The picture looks the same if other variables reported in Table 1 are examined.

Table 2 reports summary statistics of all variables in Table 1. As of 31 May 2020 , the average number of deaths in the $27 \mathrm{EU}$ member nations was 4,741 people with a positive skewness.

Table 2. Summary Statistics

\begin{tabular}{|c|c|c|c|c|c|c|}
\hline Statistic & $\begin{array}{c}\text { Population } \\
\mathbf{( 2 0 2 0} \\
\text { estimate) }\end{array}$ & Deaths & Cases & $\begin{array}{c}\text { Deaths per } \\
\text { Million } \\
\text { People }\end{array}$ & $\begin{array}{c}\text { Cases per } \\
\text { Million } \\
\text { People }\end{array}$ & $\begin{array}{c}\text { Deaths per } \\
\text { Cases }\end{array}$ \\
\hline Mean & 16579 & 4741 & 41208 & 169 & 2002 & 0.069 \\
\hline Median & 8921 & 524 & 9230 & 57 & 1234 & 0.047 \\
\hline Maximum & 83270 & 33340 & 239600 & 819 & 6359 & 0.194 \\
\hline Minimum & 516 & 7 & 616 & 5 & 274 & 0.011 \\
\hline Std. Dev. & 22300 & 9603 & 70915 & 221 & 1757 & 0.049 \\
\hline Skewness & 2 & 2 & 2 & 2 & 1 & 1.059 \\
\hline Kurtosis & 5 & 6 & 5 & 4 & 3 & 3.006 \\
\hline
\end{tabular}

Italy holds the disappointment record of over 33 thousand deaths in total and 889 deaths per million of population. The minimum total was recorded by Malta (7) but per population the minimum was recorded by Slovakia of 5 deaths per million people.

Tables 1 and 2 show large differences in the death/cases ratio. But, as explained above, this may reflect the inaccurate record of cases. France, Italy, Sweden, the Netherlands and Spain which have higher death/cases ratio may be an indication of better recording the cases but countries with low rates may as well show better provision of hospital services. This important issue goes beyond the scope of this study.

The above evidence, based on raw data, may be misleading and the underlying relationship between the size of population and the number deaths may be statistically stronger. A scatter diagram of the two variables of deaths per capita and total population is shown in Figure 1.

Larger countries were hit harder relative to smaller countries. But a careful look at Figure 1 shows that this relationship is not linear. Also, there is a cluster of small countries with population less than 10 million people. But even this subsection shows a negative relationship.

To ascertain non-linear effects, a regression equation was estimated of deaths per population as a function of total population. The results are reported in Table 3. The regression results show that population size does have an impact on the deaths per capita.

Three estimations are reported. Firstly, a logarithmic specification shows that there is positive relation between deaths per capita and population. The elasticity is 0.49 . A $1 \%$ increase in population size is associated with $0.49 \%$ increase in the number of deaths per capita. The relationship is positive. Higher populations increase the number of deaths per capita. 
Figure 1. Deaths per Capita and Total Population

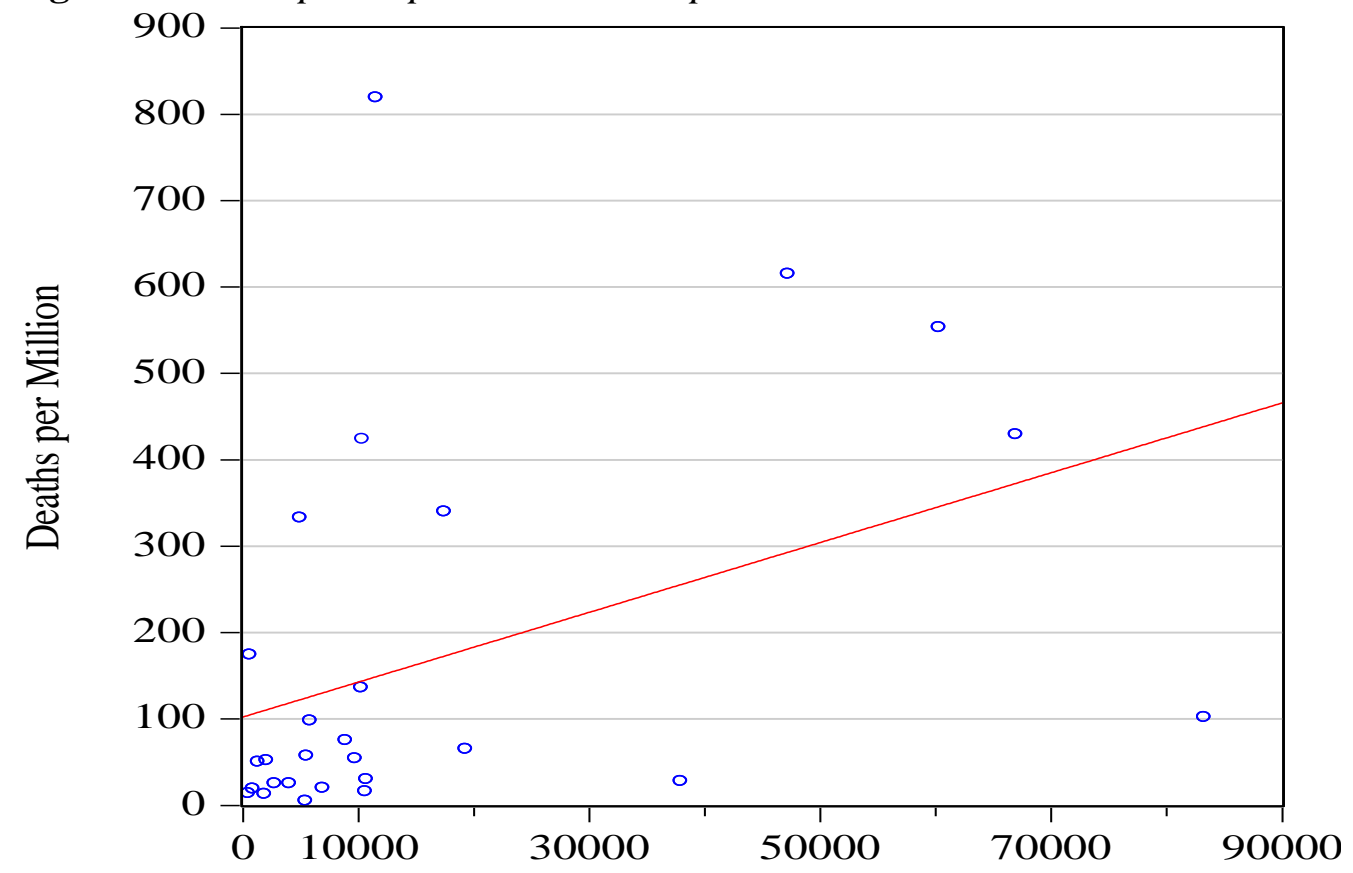

Total Population in OOOs

Table 3. Regression Results of Deaths per Million of People

\begin{tabular}{|l|c|c|c|}
\hline Explanatory Variables & $\begin{array}{c}\text { Log (Deaths per Capita) } \\
\text { (1) }\end{array}$ & $\begin{array}{c}\text { Deaths per Capita } \\
\text { (2) }\end{array}$ & $\begin{array}{c}\text { Deaths per Capita } \\
\text { (3) }\end{array}$ \\
\hline \multirow{2}{*}{ Constant } & -0.044 & -720.6 & 23.93 \\
& $(-0.02)$ & $(-0.67)$ & $(0.54)$ \\
\hline \multirow{2}{*}{ Log (Population) } & 0.49 & & \\
\hline \multirow{2}{*}{ Population } & $(3.0)$ & 0.3294 & 0.017 \\
& & $(2.74)$ & $(2.21)$ \\
\hline \multirow{2}{*}{ (Population) } & & & $-1.73 \mathrm{E}-07$ \\
& & & $(-1.8)$ \\
\hline Adjusted R-squared & 0.2029 & 0.1334 & 0.2253 \\
\hline F-statistic & 7.62 & 5.01 & 4.78 \\
\hline Prob(F-statistic) & 0.01 & 0.03 & 0.02 \\
\hline
\end{tabular}

t- values in parentheses (a t-value above 1.8 shows that the coefficient is statistically significant at $10 \%$ level). White heteroskedasticity-consistent standard errors \& covariance estimates are reported.

Secondly, a linear model on levels also shows a strong positive relation between deaths per capita and total population. However, as shown in the last column of Table 3, the relationship is non-linear. A rise in total population increases deaths per capita at a decreasing rate.

Another interesting result is given by the coefficient of determination adjusted for degrees of freedom. In the logarithmic specification, the variation in the log of population explain $20.29 \%$ of the variations of the log of deaths per capita. In the linear and non-linear specifications, the coefficient of determination is $13.34 \%$ and $22.53 \%$ respectively.

The relationship between cases per capita and total population was not statistically significant in all three model specifications. Results are not reported. 
In addition, the age structure of population was not statistically significant either. I used total and percentages of population over 65 years old and under 14 years old. Either variable was not statistically significant. This might relate to the aggregation of data. It quite possible that at the regional level the age structure may play a role. Kashnitsky et al (2020) examined age convergence using regional EU level data. They found a strong relation between age and economic convergence. Thus, regions do matter in analyzing age structure of population. Finally, population density or the area of the country was not statistically significant either.

Summing up, the results of this section, the answer to the question "to what extent population sizes matter?" is yes. The higher the population of an EU country, the higher the death rate; the latter is measured as the number of people died from COVID-19 per million of population. Why is this the case was not answered in this paper. Possible explanations could be that higher populations imply higher concentrations of populations and higher probabilities of spreading the disease.

This picture may be incomplete if we do not look at the size of the economies of the EU countries. The next section of this paper looks at aggregate economic impacts taking into consideration the findings of this section and controlling for the effect of population sizes.

\section{Does the Economy Matter?}

The 27 EU member states belong to the group of countries which can be called developed or relatively rich countries. However, great variations do exist within EU. From an economic point of view, large economies (those which produce a higher than average level of GDP) and rich countries (those with relatively high per capita GDP) do make a marked difference. Table 4 reports raw data on total and per capita GDP for the 27 EU countries.

One of the characteristics of the economy of the EU countries is different sizes. Small economies such as Malta, Cyprus, Estonia, Latvia, Slovenia, Lithuania, Croatia, Bulgaria, Luxembourg and Slovakia of less than 100 billion euro of GDP coexist with large economies Germany (3.4 trillion $€$ ), France (2.4 trillion), Italy (1.8 trillion) and Spain (1.2 trillion $€$ ). In the middle there are medium sized economies of higher 100 billion $€$ and lower one trillion $€$. Almost half of the EU economies (13) are in the middle.

This is very important because the COVID-19 has had so far, a greater impact on long-term economic prospects of an individual country and an overall impact on the EU countries since their economies are integrated especially those which at the same time are members of the eurozone. 
Table 4. GDP, Per Capita GDP and Social Spending of the 27 European Union Member States, 2019

\begin{tabular}{|l|c|c|c|}
\hline Country & $\begin{array}{c}\text { GDP } \\
\text { (millions } € \text { ) }\end{array}$ & $\begin{array}{c}\text { GDP per Capita } \\
\text { (in } € \text { ) }\end{array}$ & $\begin{array}{c}\text { Social Spending } \\
\text { (\% of GDP) }\end{array}$ \\
\hline Belgium & 473085 & 41195 & $20.7 \%$ \\
\hline Bulgaria & 60675 & 8678 & $12.1 \%$ \\
\hline Czechia & 220201 & 20632 & $14.5 \%$ \\
\hline Denmark & 310937 & 53438 & $17.9 \%$ \\
\hline Germany & 3435210 & 41336 & $17.9 \%$ \\
\hline Estonia & 28037 & 21117 & $13.5 \%$ \\
\hline Ireland & 347215 & 70373 & $8.7 \%$ \\
\hline Greece & 187457 & 17500 & $21.8 \%$ \\
\hline Spain & 1245331 & 26401 & $19.4 \%$ \\
\hline France & 2425708 & 36330 & $23.6 \%$ \\
\hline Croatia & 53937 & 13251 & $15.3 \%$ \\
\hline Italy & 1787664 & 29627 & $24.9 \%$ \\
\hline Cyprus & 21944 & 24925 & $15.0 \%$ \\
\hline Latvia & 30476 & 15941 & $12.8 \%$ \\
\hline Lithuania & 48433 & 17344 & $15.3 \%$ \\
\hline Luxembourg & 63516 & 102343 & $18.9 \%$ \\
\hline Hungary & 143826 & 14720 & $12.3 \%$ \\
\hline Malta & 13277 & 26523 & $9.8 \%$ \\
\hline Netherlands & 812051 & 46804 & $11.4 \%$ \\
\hline Austria & 398682 & 44905 & $19.5 \%$ \\
\hline Poland & 529029 & 13939 & $16.9 \%$ \\
\hline Portugal & 212319 & 20661 & $18.2 \%$ \\
\hline Romania & 223337 & 11503 & $13.4 \%$ \\
\hline Slovenia & 48007 & 22962 & $17.8 \%$ \\
\hline Slovakia & 94171 & 17266 & $16.1 \%$ \\
\hline Finland & 240078 & 43485 & $20.2 \%$ \\
\hline Sweden & 474148 & 46128 & $13.5 \%$ \\
\hline Average EU & 515880 & 31457 & $16.3 \%$ \\
\hline Median EU & 220201 & 24925 & $16.1 \%$ \\
\hline Standard Deviation EU & 815553 & 20750 & 0.04 \\
\hline Sowce: & & \\
\hline
\end{tabular}

Source: https://ec.europa.eu/eurostat/web/national-accounts/overview

However, one expects a time lag of this impact. The lockdown of 2020 cannot affect the GDP of 2019. And this makes the interpretation of the simple regression results very difficult. The question though here is not if the COVID-19 will have a negative impact on the economy and how severe will that be but whether the large economies of the EU were hit harder. The hypothesis is whether the higher the total GDP, the higher the deaths per million people.

Table 4 shows the distribution of per capita GDP between the 27 EU countries. As was the case with the observations with total GDP, so with per capita GDP the EU countries can be categorized into three groups of equal size of nine countries.

The richest group of EU countries with a per capita GDP of more than 40 thousand euro in 2019 were: Luxembourg, Ireland, Denmark, Netherlands, Sweden, Austria, Finland, Germany and Belgium. 
The poorest group of countries (with a per capita income less than 20 thousand euro) were: Bulgaria, Romania, Croatia, Poland, Hungary, Latvia, Slovakia, Lithuania and Greece.

Between 20 and 40 thousand per capita GDP were the countries of Czechia, Portugal, Estonia, Slovenia, Cyprus, Spain, Malta, Italy and France.

The average economy of EU had a GDP of 515 billion. The median value was 220 billion euro which shows the skewness of the distribution of total GDP between the $27 \mathrm{EU}$ countries as this is also portrayed by the high standard deviation of 816 billion euro.

Per capita GDP is not as disperse as total GDP but variations do exist. The average per capita GDP is 31.5 thousand euro, the median is 24.9 thousand and the standard deviation is 20.6 thousand euro.

Social spending as a percentage of GDP does show variations but are not as huge as the variations in GDP and per capita GDP. It seems that the EU countries have harmonized their social spending even though it belongs to national authorities to adjust their social spending.

How do all these economic variables impact on the deaths due to COVID-19? Table 5 reports regression results of an extended simple model which in addition to population now includes economic variables.

Many specifications were tried but they were not given statistically meaningful results. For example, the logarithmic specification was not statistically significant. This might be explained by the non-linearity of deaths per capita and the economic variables of total GDP and GDP per capita.

Table 5. Regression Results of Deaths per Population of an Extended Model

\begin{tabular}{|l|l|l|l|c|}
\hline Dependent Variable: Deaths per Million of Population & \\
\hline Variable & Coefficient & Std. Error & t-Statistic & Prob. \\
\hline C & 564.2439 & 462.4751 & 1.220052 & 0.2354 \\
\hline Per Capita GDP & 11.66524 & 5.934804 & 1.965564 & 0.0621 \\
\hline (Per Capita GDP) $^{2}$ & -0.092133 & 0.051239 & -1.798094 & 0.0859 \\
\hline Social Spending-\% of GDP) & -9778.335 & 4636.092 & -2.109176 & 0.0465 \\
\hline${\text { Social Spending-\% of GDP })^{2}}^{2}$ & 34110.32 & 13076.45 & 2.608532 & 0.0160 \\
\hline R-squared & 0.416792 & F-statistic & 3.930602 \\
\hline Adjusted R-squared & 0.310754 & Prob(F-statistic) & 0.014827 \\
\hline & \multicolumn{3}{|l|}{ Prob (Wald F-statistic) } & 0.000002 \\
\hline
\end{tabular}

White heteroskedasticity-consistent standard errors \& covariance estimates are reported.

Also, the size of population and GDP are correlated and this creates a problem of multicollinearity. The effect of these two variables cannot be ascertained separately. Instead, per capita income is used as an explanatory variable of deaths per capita.

Total deaths instead of per capita deaths give different statistical results. The GDP variable was not statistically significant. Table 5 reports the regression results of only a model of statistically significant coefficients. Per capita income and social spending as percentage of GDP were used as explanatory variables. The effect of both variables is non-linear. 
Table 5 shows that economic variables do matter. It seems that the economies which were hit the hardest were the richer countries of EU. Countries with higher than average GDP per capita recorded higher than average deaths per capita but at a decreasing rate. On the other hand, social policy spending does matter. Countries with higher spending reported lower number of deaths per capita.

In concluding, the economy does matter. The richer the country, the higher the deaths per capita. On the other hand, the higher the social spending as a share of GDP, the lower the ratio of deaths to population. It seems that social policy does work and EU countries should consider coordinate and consolidate a common policy. This issue is briefly discussed in the next section of this paper in light of the current pandemic.

\section{A Common EU Policy to Fight the Current Pandemic}

The members of EU are not obliged to follow a common social policy and to that extent any policy which relates to public spending on education, health and welfare. Over the years this has created two problems.

The first is ideological. There is no doubt that the European Civilization has been at the forefront of what one may call an anthropocentric society. Never before and nowhere today the humanity has reached such levels of civilization as in EU. And this must be cherished by all European countries. Despite the differences shown by some countries which in statistical terms can be considered outliers, the European Civilization is the best humanity ever had. It is at the highest point of a steep mountain where at the top lies the ideal society. The European civilization is not perfect but it is the best. A demonstration of such a superior civilization is the treatment of all kind of minorities included those people who suffer more from the current pandemic. The European Union has not shown the solidary which one would expect from its superior civilization. Ideology relates to politics and the latter to democracy.

Pandemics affect political and social processes at least in the short term over the political cycle. Haffoudhi and Bellakhal (2020) have related democracy to age structure and demography. COVID-19 has had a differential age structure effect and this might have repercussions on the political process in the EU countries. Also, as Krieger and Meierrieks (2020) population size is positively related with government size. If this is the case, then EU countries with larger population which were hit harder with the COVID-19 may expect political instability and pressure as they will account the government responsible for the impact.

Related to this issue of democracy and politics is the fertility rate of women. Sommer (2018) using a sample of 140 countries found growth in democracy when fertility declines. A future study should examine how countries which differ in fertility rates and therefore in the role of women in politics have performed in terms of social policy and coping with the pandemic.

The second is economics. Countries who spend more on social policies which in some cases might include minimum wages financed by higher tax rates and less investment credits put themselves in a disadvantageous position than the other 
countries of EU that use a curtailment of social benefits as a means to promote short-run economic growth objectives.

Both reasons are important. I do not suggest an increase or a decrease in social policy spending. What I do suggest is that the European Union must decide what kind of society it wants and one this decision is reached, then it must be applied to all countries. If some countries do not follow, they must not be part of the European Union; spiritually at least.

The current pandemic has sown the lack of a common policy to face the economic and social problems. Countries under panic started to take measures without consulting each other creating a deplorable situation. However, I must stress that relative to U.K. and USA, the European Union looks like a paradise. And if for the EU there is an excuse because 27 countries must coordinate their actions after a common decision is taken, for the other areas of the world there is no excuse. Table 6 reports comparative data of the EU, UK, Canada and USA. With exception of Canada, USA and U.K. have scored below the E.U. average.

Table 6. Comparative Summary Statistics of EU, U.K., Canada and USA

\begin{tabular}{|l|c|c|c|c|c|}
\hline $\begin{array}{l}\text { Area or } \\
\text { Country }\end{array}$ & Population & Deaths & Cases & $\begin{array}{c}\text { Deaths per } \\
\text { Million of People }\end{array}$ & $\begin{array}{c}\text { Cases per } \\
\text { Million of People }\end{array}$ \\
\hline EU & 449641 & 128007 & 1112611 & 285 & 2474 \\
\hline U.K. & 67192 & 38376 & 272830 & 571 & 4060 \\
\hline Canada & 36475 & 6996 & 89741 & 192 & 2460 \\
\hline USA & 333245 & 101567 & 1716078 & 305 & 5150 \\
\hline
\end{tabular}

Finally, on the 13 May 2020, the EU took a number of initiatives which are stated in four documents (European Commission 2020a, 2020b, 2020c and 2020d). In what follows in this section, I make a few notes on them.

In my earlier paper (Papanikos 2020b), I indicated that the important issue was to reach a common decision to lift the variations in the lockdown policies. What is missing from these documents is the emphasis on the demand side of the equation or the consumer behavior. As long as countries report even a single case of infection, people will not resume traveling or undertake any other outdoor activity such as dining and shopping.

There is a demographic side to this story. Given the evidence that the disease hit disproportionally the older people, then governments must increase their spending targeting this age group. This might require a rationalization and restructuring of health services. Currently there is no common health policy even at the level of absorbing excess demand shocks. This is a research question which needs further investigation: how health expenditures affected the deaths and cases of Covid-19.

The recent discussion at the EU level to spend billions of euro to revitalize the economy to get out of the upcoming deep recession is towards the right direction. I consider it necessary but not sufficient. The EU must take common social policy measures which will include health provision. The EU has established a European University in 1972 even though the provision of education at all levels are regulated by each national government of member states. 
I would like to see that extended to health provision. For example, I would like to see a top research oriented gigantic hospital with thousands of beds which will serve the European Citizens. One of its statutory obligations is to absorb excess demands at the EU level. It will work the same way as an insurance market. The larger the population, the lower the cost.

In the current pandemic, such as a European Hospital would have provided the facilities for a widespread testing, isolation of those affected, contact tracing and quarantine of those contacts. Given that the spread was a pan-European one, a European common action would probably have prevented the loss of lives and the mass lockdowns.

\section{Conclusions}

Population size and the economy do play a role in explaining variations in deaths due to Covid-19 in EU countries.

A one percent increase in population size is associated with $0.49 \%$ increase in the number of deaths per capita. But the relationship is non-linear. More populated countries were hit harder by Covid-19 but the rate of impact decreases as population size increases.

On the other hand, the economy does matter. The richer the country, the higher the deaths per capita. On the other hand, the higher the social spending as a share of GDP, the lower the ratio of deaths to population.

It seems that social policy does work and EU countries should consider coordinate and consolidate a common policy.

\section{References}

Court V, McIsaac F (2020) A Representation of the World Population Dynamics for Integrated Assessment Models. Environmental Modeling \& Assessment [forthcoming] https://doi.org/10.1007/s10666-020-09703-z

European Commission (2020a) Tourism and transport in 2020 and beyond. COM(2020) 550. Retrieved from https://bit.ly/2zMXRmU.

European Commission (2020b) Communication from the Commission: Covid-19 - Towards a phased and coordinated approach for restoring freedom of movement and lifting internal border controls. C (2020) 3250 final. Retrieved from: https://bit.ly/2LESxVh.

European Commission (2020c) Covid-19: guidelines on the progressive restoration of transport services and Connectivity. C(2020) 3139 final. Retrieved from https://bit.ly/ 3bI9sRt.

European Commission (2020d) Commission recommendation of 13.5.2020 on vouchers offered to passengers and travelers as an alternative to reimbursement for cancelled package travel and transport services in the context of the Covid-19 pandemic. $\mathrm{C}(2020)$ 3125 final. Retrieved from https://bit.ly/3cW2Lgh.

Haffoudhi H, Bellakhal R (2020) Threshold Effect of Globalization on Democracy: The Role of Demography. Journal of the Knowledge Economy 56. https://doi.org/10.1007/s13132020-00639-Z 
Vol. 7, No. $4 \quad$ Papanikos: The Demographics of Covid-19 in the European Union

Kashnitsky I, De Beer J, Van Wissen L (2020) Economic Convergence in Ageing Europe. Tijdschrift voor economische en sociale geografie 111(1): 8-44.

Krieger T, Meierrieks D (2020) Population size and the size of government. European Journal of Political Economy 61.

Lee R (2003) The Demographic Transition: Three Centuries of Fundamental Change. Journal of Economic Perspectives 17(4): 167-190.

Malthus T (1798 \& 1830) An Essay on the Principle of Population and a Summary View of the Principle of Population. Edited by Anthony Flew. Great Britain: Penguin Books (1979).

Papanikos GT (2020a) Thucydides and the synchronous pandemic. Athens Journal of History [forthcoming]: 1-26. Retrieved from https://bit.ly/2z9YvLh.

Papanikos GT (2020b) The Impact of the Covid-19 Pandemic on Greek Tourism. Athens Journal of Tourism, 7(2): 87-100.

Sommer U (2018) Women, Demography, and Politics: How Lower Fertility Rates Lead to Democracy. Demography 55: 559-586. 